\title{
Основні вимоги до TLAA та практика їх застосування в Україні та світі
}

- Шугайло Олексій Петрович, канд. техн. наук Державне підприємство «Державний науково-технічний центр з ядерної та радіаційної безпеки», м. Київ, Україна ORCID: https://orcid.org/0000-0003-0997-7830

- Казимирська Оксана Іванівна Відокремлений підрозділ «Рівненська атомна електрична станція» Державного підприємства «Національна атомна енергогенеруюча компанія «Енергоатом», м. Вараш, Рівненська обл., Україна ORCID: https://orcid.org/0000-0001-9306-7447

- Брік Дмитро Семенович

Державне підприємство «Державний науково-технічний центр з ядерної та радіаційної безпеки», м. Київ, Україна ORCID: https://orcid.org/0000-0003-2971-1802

- Чумель Богдан Олександрович

Державне підприємство «Державний науково-технічний центр з ядерної та радіаційної безпеки», м. Київ, Україна ORCID: https://orcid.org/0000-0002-6961-5551

- Банько Світлана Миколаївна

Державне підприємство «Державний науково-технічний центр з ядерної та радіаційної безпеки», м. Київ, Україна ORCID: https://orcid.org/0000-0002-5316-9227

Управління старінням розглядається як один з основних факторів забезпечення безпеки ядерних установок на етапах проєктної та довгострокової експлуатації. Тому аналізу стану питання управління старінням приділяється відповідна увага і в Україні й у світі. Однією з основних складових робіт з управління старінням $\epsilon$ виконання аналізів старіння, що визначають строк служби, так званих - TLAA (Time Limited Ageing Analysis). Фактично саме результати TLAA можуть бути інтерпретовані як строк продовження експлуатації конкретного елемента або конструкції. У цій статті наведені основні результати аналізу практики застосування TLAA у країнах Європи та США, досвіду України щодо переходу до довгострокової експлуатації на основі TLLA, виконано співставлення національних та міжнародних підходів до вимог TLAA, а також зроблено відповідні висновки.

Ключові слова:TLAA, аналіз безпеки, довгострокова експлуатація, ефекти старіння, управляння старінням, періодична переоцінка безпеки.

() Шугайло О-й П., Казимирська О. І., Брік Д. С., Чумель Б. О., Банько С. М., 2021

Відповідно до рекомендацій Міжнародного агентства 3 атомної енергії (МАГАТЕ) SSR-2/2 [1] ефективне управління старінням (УС) елементів і конструкцій (ЕіК) $\epsilon$ одним із ключових аспектів безпечної та надійної експлуатації АEC, роль якого зростає з роками експлуатації і набуває особливого значення під час переходу до довгострокової експлуатації (ДСЕ). 
Ефективне УС під час експлуатації енергоблока вимагає системного підходу, що є основою для координації всіх програм і заходів, пов'язаних із розумінням, контролем, управлінням і пом'якшенням процесу деградації.

Однією із важливих складових елементів УС під час переходу до ДСЕ $\epsilon$ виконання аналізів старіння, які визначають строк служби і демонструють, що впродовж усього часу, на який виконано аналіз, значення параметрів технічного стану (ПТС) конкретного елемента, конструкції не будуть перевищувати критерії, встановлені в нормах, правилах і стандартах з ядерної та радіаційної безпеки (ЯРБ) та проєктній документації. У світовій практиці такий аналіз має назву TLAA (Time Limited Ageing Analysis), зустрічаються також назви - Time Limited Assumptions (TLA) або Residual Life Assumptions (RLA). TLAA, TLA або RLA - це різні назви однієї і тієї ж діяльності. За своєю суттю це оцінка виявленого ефекту старіння (через деградацію під час експлуатації) із застосуванням відповідного аналізу безпеки для конкретної АEC, заснованого на підтвердженні строку експлуатації EiK AEC (наприклад, на період 10, 20 або 30 років). TLAA ґрунтується на розрахунках і аналізі, які визначені заявником як такі, що мають вплив на безпеку.

TLAA застосовуються для важливих компонентів 1-го контуру ядерної установки (ЯУ), окремих елементів, конструкцій і споруд, наприклад, таких як захисна оболонка (30).

Загалом TLAA - це комплекс аналітичних робіт, проведених з урахуванням невизначеностей вихідних даних, особливостей AEC і зважаючи на чітко визначений строк експлуатації АЕC.

\section{1 Основні вимоги та критерії успішності TLAA згідно з рекомендаціями MAГATE}

Відповідно до положень SSG-48 [2] УС для АEC здійснюється 3 метою забезпечення того, щоб ефекти старіння не перешкоджали виконанню системами, конструкціями і компонентами своїх проєктних функцій безпеки протягом усього строку експлуатації AEC (включно з її виведенням 3 експлуатації). Це вимагає врахування як наслідків фізичного старіння систем, конструкцій і компонентів, що призводять до погіршення їх експлуатаційних характеристик, так і нефізичного/ морального старіння систем і компонентів (тобто їх старіння порівняно з поточними станом розвитку науки і техніки). УС $є$ найбільш ефективним, якщо воно здійснюється на постійній основі і на всіх етапах життєвого циклу АЕС.

Одним з основоположних аспектів під час переходу до ДСЕ $\epsilon$ виконання TLAA, який, згідно 3 SSG-48 [2], має відповідати таким критеріям:

1) містити EiK, що розглядаються в межах УС;
2) ураховувати ефекти старіння (зокрема такі як: втрата матеріалу, зміна розмірів, зміна властивостей матеріалу, втрата ударної в'язкості, втрата попереднього напруження, розтріскування, втрата діелектричних властивостей тощо);

3) містити обмежені в часі допущення протягом визначеного строку експлуатації;

4) відповідати вимогам безпеки відповідно до національних нормативних документів;

5) містити висновки або забезпечувати основу для висновків щодо здатності конструкцій, систем і компонентів виконувати свої функції;

6) входити до чинної ліцензійної основи, включно, але не обмежуючись, зі звітами з аналізу безпеки, нормативними документами, звітами 3 оцінки безпеки, планами протипожежного захисту, листуванням з регулюючим органом, документацією системи менеджменту і тематичними звітами, на які $\epsilon$ посилання в звітах з аналізу безпеки.

TLAA оцінюється 3 використанням прогнозного значення параметра, що залежить від строку експлуатації, наприклад, через розрахунок флюенсу нейтронів для певного періоду експлуатації. Це значення параметра, який залежить від строку експлуатації (наприклад, від проєктного значення флюенсу нейтронів), має використовуватися для оцінки певних параметрів аналізу, таких як скоригована температура крихкості або в'язкість руйнування.

Достовірність TLAA протягом передбачуваного періоду експлуатації підтверджується за допомогою демонстрації відповідності одному з таких критеріїв SSG-48 [2]:

1) результати проведеного аналізу залишаються чинними протягом перепризначеного строку служби і далі;

2) прогнозування робиться на кінець періоду перепризначеного строку служби і не більше;

3) вплив процесу старіння на виконання призначених/установлених для ЕіК функцій має адекватно контролюватись і регулюватись протягом призначеного/перепризначеного строку служби;

4) якщо TLAA не $\epsilon$ прийнятним з використанням критеріїв, які наведені вище, то вживаються коригувальні дії, а саме: уточнення аналізу для усунення надмірного консерватизму; втілення коригувальних заходів щодо експлуатації, технічного обслуговування або внесення додаткових заходів до програми управління старінням (ПУС); модифікація, ремонт чи заміна конструкції або компонента.

Результати оцінки TLAA повинні використовуватися як вихідні дані для формування підходів з УС. TLAA застосовуються майже в усіх країнах, які експлуатують атомні станції і планують перехід або вже перейшли до ДСЕ. Нижче наведені конкретні приклади застосування TLAA у деяких зарубіжних країнах. 


\section{2 Практика застосування TLAA в країнах Європи та США}

США. Однією із перших країн, яка розпочала застосування TLAA на практиці для обгрунтування можливості продовження дії ліцензії, $є$ США. Одним із основних нормативних документів США, який містить вимоги до обгрунтувань і документації експлуатуючої організації (EO) у разі продовження ліцензії, $\epsilon$ документ «10 CFR Part 54 Requirements for Renewal of Operating Licenses for Nuclear Power Plants» [3] (загальні вимоги до оновлення ліцензії на експлуатацію AEC).

Відповідно до вимог 10 CFR [3] TLAA - це розрахункові обгрунтування і аналізи ліцензіата, які: містять системи, конструкції і компоненти в межах продовження ліцензії; враховують процеси старіння; враховують обмежені в часі допущення; були визначені ліцензіатом як такі, що стосуються визначення безпеки; $\epsilon$ основою для висновків щодо спроможності системи, конструкції і компонента виконувати свої функції на запланований період експлуатації; наведені в чинних нормах і правилах.

Крім регулюючих документів щодо продовження строку експлуатації в США існують індустріальні (промислові) документи, які уточнюють і конкретизують положення федеральних норм і правил, як, наприклад, документ «NEI 95-10, Industry Guidelines for Implementing the Requirements of 10 CFR 54 The License Renewal Rule, Revision 6, June 2005» [4], цілями і завданнями якого, зокрема, $\epsilon$ визначення об'єктів для виконання TLAA, оцінка результатів TLAA.

На Рисунку 1 зображено узагальнену схему оцінки TLAA у США.

Результати TLAA і оцінки винятків повинні бути задокументовані в форматі, сумісному 3 іншими форматами документування AEC. Інформація може зберігатися в друкованому або електронному вигляді. За необхідності, інформацію може бути внесено в існуючу базу даних АЕС. Заявник повинен використовувати чинну на AEC програму забезпечення якості документування результатів TLAA і оцінки винятків.

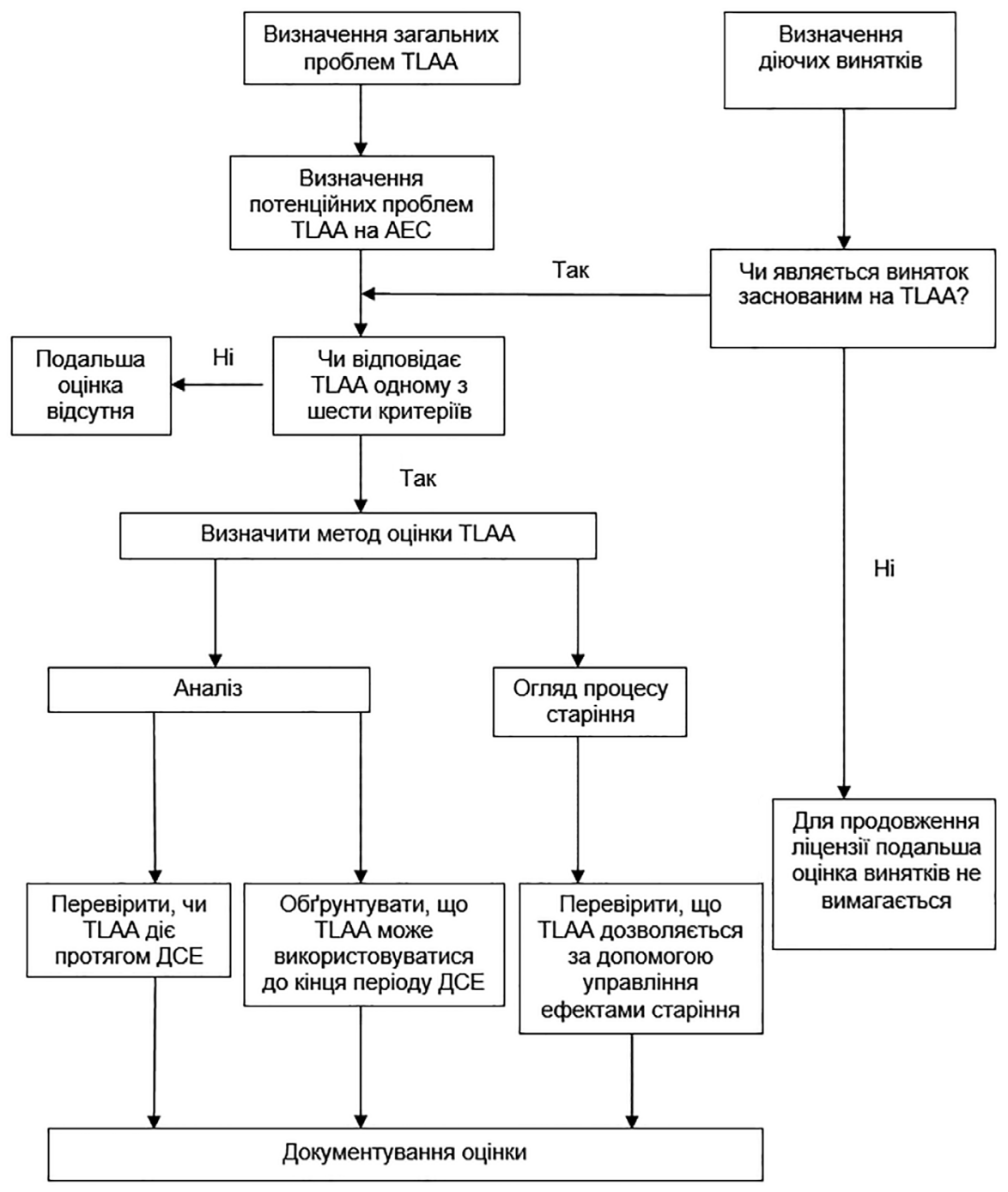

Рисунок 1 - Схема оцінки TLAA і винятків 
Нідерланди. Відповідно до положень стандарту МАГATE SSG-25 [5] кожні 10 років проводиться комплексна періодична переоцінка безпеки (ППБ). Документом, який описує процедуру виконання TLAA на період ДСЕ у Нідерландах $\epsilon$ «Conceptual document NRG-22701 / 10.10346024» [6], що містить вимоги, порядок та обсяги робіт з виконання аналізу УС і TLAA.

Згідно $з$ положеннями NRG-22701/10.10346024 [6] було визначено такі основні напрями TLAA: корпус реактора (КР) (радіаційне окрихчення, втома); втома металу; теча перед руйнуванням; кваліфікація проєктного базового електрообладнання, стійкого до аварій.

Швеція. Згідно з нормативними підходам Швеції до оцінки безпеки ЯУ, TLAА розглядає ті аналізи, для яких у початкові розрахунки були внесені обмеження щодо часу для визначення розрахункового строку експлуатації ЯУ.

У Швеції загальний підхід до оцінки безпеки в межах проведення ППБ, реалізації ПУС та виконання TLAA, встановлюється відповідно до рекомендацій МАГАTE (SRS 82 (IGALL) [7]) і вимог національного нормативного документа SSMFS 2008:17 [8] з урахуванням положень документа США NUREG 1801 [9].

Підходи до аналізу старіння на АЕС Швеції дещо відрізняються один від одного. На АЕС Форсмарк і Оскарсхамн TLAA входять до ПУС, водночас на AEC Рінгхальс проведення і оцінка TLAA були виконані під час переоцінки безпеки, а не як складова частина ПУС. За результатами робіт з ППБ на АЕС Рінгхальс Шведським регулятором був зроблений висновок, що вилучення аналізів, які використовують обмежені за часом допущення, із загальної ПУС може призвести до непотрібної плутанини, оскільки використання TLAA $є$ одним із способів УС. На міжнародному рівні (як, наприклад, чинний до недавнього часу документ МАГАTE NS-G-2.12 [10]) TLAА внесені до загальної ПУС.

Якщо TLAA не буде визнаний прийнятним в одному з вищеописаних випадків, виконуються коригувальні дії (наприклад, уточнення розрахункових обгрунтувань, оптимізація ремонту, впровадження компенсуючих заходів тощо).

Словенія. Через відсутність ядерного законодавства в колишній Югославії, АЕС Кршко була споруджена відповідно до нормативної бази КЯР США (10 CFR Part 50 Domestic Licensing of Production and Utilization Facilities [11]). Зі свого боку ПУС АЕС базується на регулюючих і індустріальних документах США 10CFR [3], NEI 95-10 [12]), а також ураховано положення NUREG 1800 [13] і NUREG-1 801 [9], які встановлюють стандартні критерії прийнятності для ПУС.

NUREG-1800 [13] і 10 CFR [3] визначають TLAA як комплекс розрахункових обгрунтувань і аналізів для конкретного елемента, конструкції, які засновані на визначеному часі експлуатації або проєктному періоді служби і проводяться для кон- кретної АЕС. Відповідно до вимог 10CFR [3] проводиться оцінка TLAA для підтвердження того, що: аналізи залишаються дійсними протягом періоду ДСЕ; аналізи розроблені до кінця періоду ДСЕ; або вплив процесу старіння на проєктну(i) функцію(i) буде регулюватися протягом періоду ДСЕ.

Незважаючи на те, що підходи до виконання робіт з оцінки старіння в Словенії засновані на положеннях документів КЯР США, ПУС АЕС загалом керується вказівками МАГАTE (IAEA SRS № 82 [8]), що стосуються програмних аспектів, таких як організація та методологія ПУС включно з виконанням TLAA.

Іспанія. Регулюючий орган Іспанії (CSN) встановлює вимоги до УС в таких документах як Інструкція про вимоги безпеки IS-22 [14] для УС i ДСЕ АЕС; Керівництво з безпеки (SG) 1.10 [15] щодо періодичних оцінок безпеки $\mathrm{AEC}$, що проводяться кожні 10 років.

Відповідно до положень документів IS-22 [14] і SG 1.10 [15] для підтвердження безпечної експлуатації протягом ДСЕ на АЕС Іспанії необхідно вжити такі заходи:

розробити комплексну оцінку станції, яка узагальнює технічне обґрунтування УС щодо ДСЕ та містить дослідження з УС і TLAА;

розробити і реалізувати довгострокову ПУС, засновану на висновках комплексної оцінки станції та відповідній програмі дій з управління життєвим циклом протягом ДСЕ.

Методологія розробки ПУС іспанських АЕС переважно базується на методиці, наведеній у документах КЯР США 10 CFR [3] і NUREG 1801 [9], та враховує рекомендації таких документів, як NEI 95-10 [12], SRS № 82 (IGALL) [8], SSG-48 [2], SRS № 57 [16].

Оцінка TLAA проводиться відповідно до положень IS-22 [14] і використовує один із таких методів: перевірка того, що поточні аналізи і розрахунки дійсні для періоду ДСЕ, тому виконувати новий аналіз не потрібно; переоцінка поточних аналізів і розрахунків для періоду ДСЕ і перевірка відповідності критеріям прийнятності; демонстрація того, що ефектами старіння можна керувати протягом періоду ДСЕ, встановленого за допомогою ПУС.

Інші країни ЄC (Франція, Чехія, Фінляндія, Угорщина). У Франції, наприклад, у межах підготовки до ППБ (10 років) діє ПУС, розроблена з метою обґрунтування того, що всі системи, конструкції і компоненти, пов'язані $з$ механізмом старіння, залишаються в межах застосовних критеріїв проєктування і безпеки. Процедура ПУС, що відповідає положенням МАГАTE SSG-48 [2], виконується в три основних етапи, а саме: вибір ЕіК, важливих для безпеки, на які впливає процес старіння; розгляд всіх систем, конструкцій і компонентів, на які впливає процес старіння, і що визначаються експериментально з використанням таблиць аналізу старіння.

Кожна АЕС надає звіти про УС в регулюючий орган з ядерної безпеки не пізніше ніж за 12 місяців 
до закінчення десятирічного періоду експлуатації. Звіт повинен обґрунтувати можливість продовження строку експлуатації AEC на 10 років.

У Чеській Республіці не розробляються окремі документи, які встановлюють вимоги до виконання TLAA. Відповідно до документа Decree No. 162 [17] оцінка безпеки, яка проводиться за 24 місяці до закінчення строку експлуатації ядерного реактора, повинна містити відомості щодо: ступеня деградації ЕіК та можливості подальшого виконання проєктних функцій; надійності систем, ЕіК; збереження функцій безпеки 3 урахуванням процесів старіння; достовірності і коректності TLAA; ефективності накопичення знань і досвіду експлуатації, отриманих протягом попереднього життєвого циклу ЯУ.

Крім того, вплив процесу старіння на системи, ЕіК оцінюється в межах звіту з періодичної оцінки безпеки відповідно до положень документа Decree No. 162 [17].

Аналогічний підхід під час проведення TLAA існує у Фінляндії. Відповідно до вимог Керівництва з УС, GUIDE YVL A.8 [18] ліцензіат зобов'язаний розробляти ПУС, яка затверджується регулюючим органом.

Водночас у всіх наведених випадках виконання і оцінка TLAA проводиться згідно з вимогами документа МАГАTE SSG-48 [2] (критерії розробки та оцінки TLAA, розробка коригувальних дій).

Підхід до TLAA, який використовується в Угорщині, дещо відрізняється.

Основними документами, які визначають загальні вимоги до виконання TLAA в Угорщині, $\epsilon$ HAEA Guideline 1.28 [19] i HAEA Guideline 4.14 (2013) [20]. Згідно з якими TLAA $\epsilon$ аналізом для обгрунтування відповідності систем, ЕіК проєктним функціям під час продовження строку експлуатації.

У документі Guideline 1.28 [19] наведені загальні підходи до визначення і впровадження заходів 3 УС замість обгрунтування того, що TLAA $є$ дійсним. Якщо строк дії TLAA не може бути продовжений за межі проєктного періоду експлуатації ЯУ, то потрібно продемонструвати, що існує можливість зменшити консерватизм, який застосовується в методі розрахунку або у вхідних даних TLAA, то в заявці на ліцензію має бути зазначено, що результати аналізу будуть дійсні без погіршення проєктних меж безпеки.

Наступним кроком розглядається національний досвід переходу до ДСЕ на основі TLAA.

\section{3 Досвід України щодо переходу до ДСЕ на основі TLAA}

Перші вимоги щодо застосування TLAA під час переходу до ДСЕ з'явились в національних нормативних вимогах із набуттям чинності НП 306.2.210-2017 [21] і визначені як «аналіз старіння, що визначає строк служби - аналіз безпеки, який ураховує старіння в часі ЕіК і обґрунтовує їх безпеку у період призначеного та перепризначеного строку служби».

Уся діяльність, пов'язана із втіленням TLAA в Україні ґрунтується передусім на стандартах з безпеки МАГАТЕ. Після введення в дію загальних регулюючих вимог до УС і ДСЕ (НП 306.2.210-2017 [21]) вони були деталізовані в галузевих стандартах ЕО (COУ HAEK 080:2014 [22] та COУ HAEK 141:2017 [23]).

Відповідно до НП 306.2.210-2017 [21] загальний перелік робіт, що виконується в межах оцінки технічного стану ЕіК для обґрунтування можливості переходу до ДСЕ, містить визначення: поточних значень ПТС ЕіК і їх відповідності критеріям прийнятності; прогнозу зміни ПТС у період ДСЕ; механізмів деградації, ефектів старіння та темпи їх розвитку; достатності існуючих заходів з УС та їх доповнення за результатами оцінки технічного стану (за необхідності); тривалості безпечної ДСЕ ЕіК на підставі результатів оцінки технічного стану та аналізу старіння, що визначає строк служби; можливості, строків та умов подальшої експлуатації ЕіК енергоблока АЕС.

Тобто TLAA $\epsilon$ однією із складових загального обсягу робіт і має на меті продемонструвати, що протягом всього строку, на який виконано аналіз, значення ПТС конкретного елемента, конструкції не буде перевищувати критерії, встановлені в нормах, правилах і стандартах з ЯРБ та проєктній документації.

У разі, якщо результати TLAA незамінних ЕіK свідчать про те, що в окремих випадках критерії прийнятності можуть бути не дотримані, впроваджуються заходи з пом'якшення ефектів старіння. Якщо такі заходи не дозволяють досягнути необхідного результату, ухвалюється рішення про зміну умов та меж безпечної експлуатації Яу.

Типові TLAA, які виконуються під час проведення ППБ для обґрунтування ДСЕ, наведені в Додатку 2 до НП 306.2.210-2017 [21].

Відповідно до СОУ НАЕК 080:2014 [22] та COУ HAEK 141:2017 [23] одним із вагомих кроків під час обґрунтування ДСЕ $є$ виконання оцінки технічного стану та проведення розрахунків на міцність. Тобто на цьому етапі може виникнути питання: а в чому різниця між розрахунками міцності для обладнання і трубопроводів та аналізом TLAA? Номенклатура обґрунтувань міцності, наприклад, для обладнання та трубопроводів чітко вказана в ПНАЭ Г-7-002-86 [24]. У разі зіставлення переліку TLAA із переліком розрахунків на міцність стає очевидним, що міцнісний розрахунок $\epsilon$ однією із складових усього переліку TLAA. Водночас не всі розрахунки міцності можуть розглядатись як аналіз TLAA. Нижче, на прикладі Відокремленого підрозділу «Рівненська атомна електростанція» (ВП РАЕС), розглянуто основні приклади TLAA, що застосовуються в Україні під час обґрунтування ДСЕ. 


\section{4 Втілення TLAA в Україні (на прикладі ВП РАЕС)}

Опір крихкому руйнуванню. Цей TLAA розглядає наслідки радіаційного окрихчення металу КР, а також встановлює вплив цього механізму деградації на результати аналізу та обмеження в часі з експлуатації КР, є обов'язковим і виконується для всіх енергоблоків на стадії проєктної експлуатації, під час переходу до ДСЕ та уточнюється під час проведення чергової переоцінки безпеки. Зазначений TLAA містить: нейтронно-фізичні розрахунки; теплогідравлічний аналіз, міцнісні розрахунки КР (з урахуванням поточних властивостей механічних характеристик КР).

Умовою, яка визначає можливість і строк безпечної експлуатації КР (Рисунок 2), є дотримання критерію опору крихкому руйнуванню.

Основними характеристиками матеріалу, що використовуються під час оцінки крихкої міцності $\mathrm{KP}, \in$ в'язкість руйнування $K_{l^{\prime}}$ критична температура крихкості $T_{K}$ і межа плинності $R_{p 0,2}^{T}$. Зміна $K_{l c}$ протягом експлуатації враховується за допомогою зміни критичної температури крихкості.

Під час підготовки енергоблока № 1 ВП РАЕС до ДСЕ виконано розрахунок КР на опір крихкому руйнуванню, який фактично визначив можливу тривалість ДСЕ енергоблока загалом. TLAА виконано для зварного з'єднання № 4, як елемента найбільш схильного до окрихчення.

Специфічною особливістю цього TLAA було те, що на той час єдиним чинним в Україні нормативним документом, який регламентував вимоги до розрахунку на опір крихкому руйнуванню, був документ ПНАЭ Г-7-002-86 [24]. Критерій опору крихкому руйнуванню згідно 3 ПНАЭ Г-7-002-86 [24] виконувався до 2011 або 2016 року залежно від прийнятого співвідношення для зсуву $\Delta T_{F}$. Ці результати розглядались як надмірно

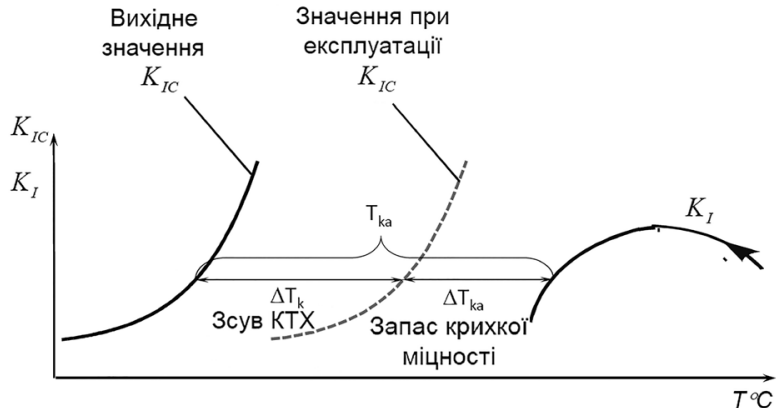

Рисунок 2 - Визначення строку експлуатації КР на підставі результатів TLAA «опір крихкому руйнуванню»

консервативна оцінка, яку зумовлено підходами в ПНАЭ Г-7-002-86 [24], що не переглядався з часів СРСР. Для зняття надлишкового консерватизму була використана більш сучасна на той час методика МРКР СXР [25], для використання якої отримано відповідний дозвіл Державної інспекції ядерного регулювання України (Держатомрегулювання). Результати аналізу старіння з використанням МРКР СХР [25] показали, що строк служби КР з позицій опору крихкому руйнуванню забезпечується протягом 40 років і 60 років (до 2040 року). Водночас, виконані на той момент дослідження зразків-свідків (3С) КР енергоблока № 1 ВП РАЕС у межах проєкту TAREG [26] показали, що вміст фосфору в 3 С зварного шва № 4 складає 0,020-0,039\%, а значення верхньої $95 \%$ огинаючої для всіх вимірювань вмісту фосфору в 3 С складає 0,041 \% і саме це значення має бути розглянуто під час оцінки зсуву $T_{\kappa}$.

Виконана в межах державної експертизи ЯРБ [27] експертна оцінка залежності $\Delta T_{F}$ та зсуву $T_{K} 3$ урахуванням уточнених даних проєкту TAREG [26] наведена на Рисунку 3, а строку безпечної експлуатації КР енергоблока № 1 ВП РАЕС з використанням залежності $T_{k}$ та вихідної і уточненої залежностей $\Delta T_{F}$ на Рисунку 4.

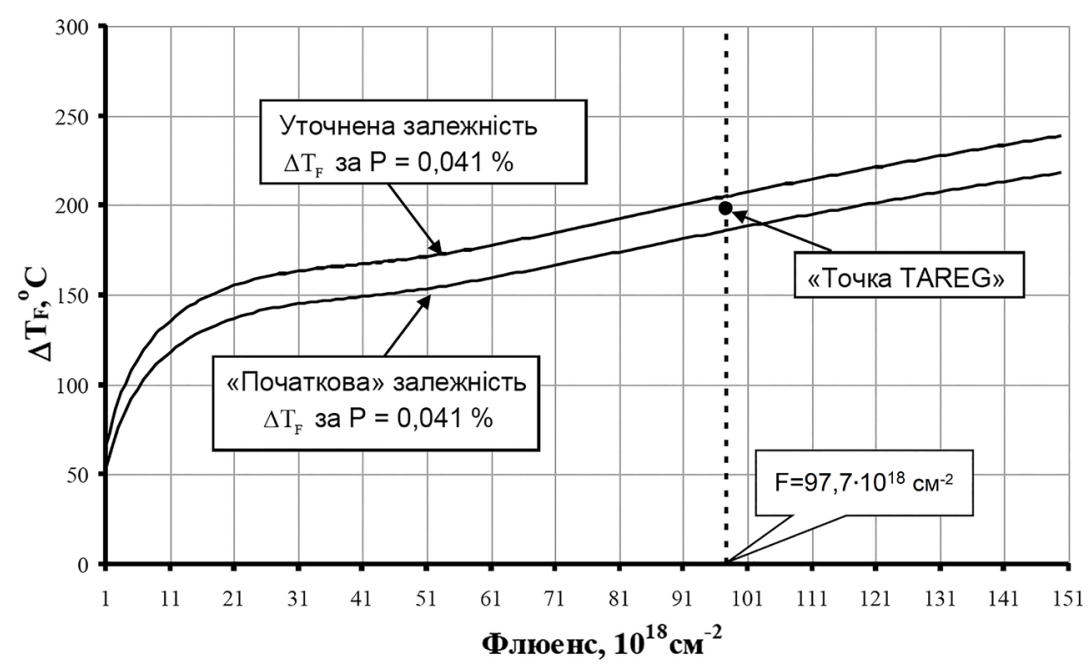

Рисунок 3 - Результати експертної оцінки консервативності початкової та уточненої залежностей $\Delta T_{F}$ відносно «точки TAREG» 


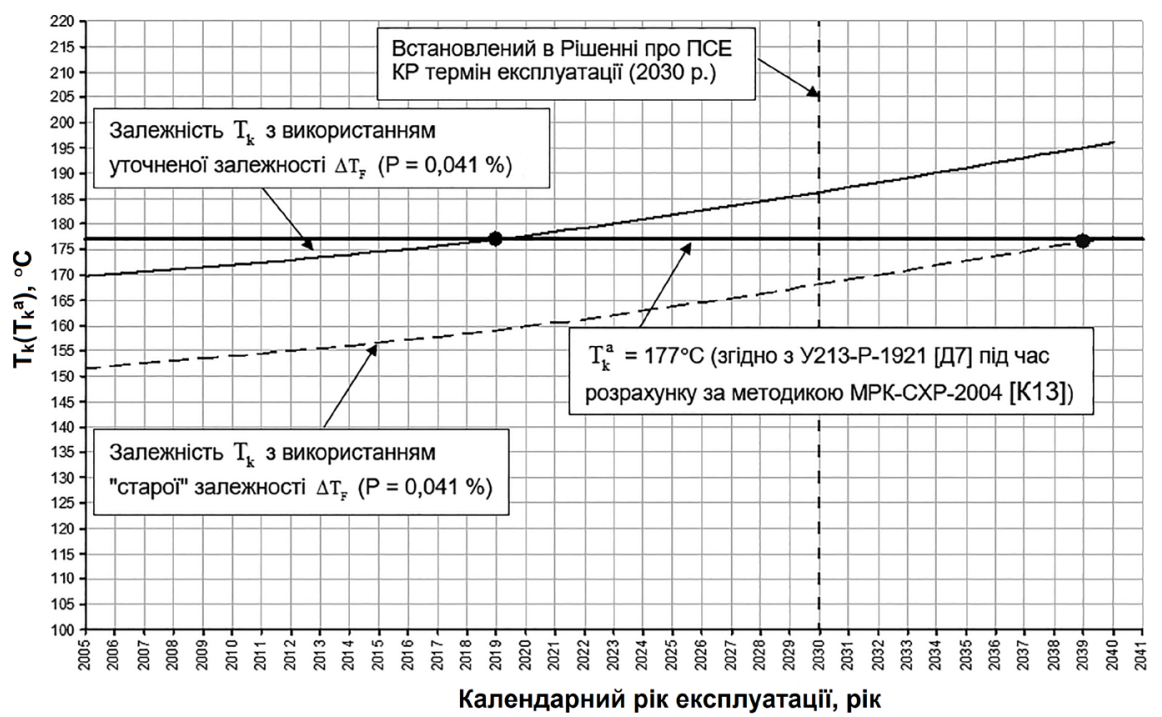

Рисунок 4 - Експертна оцінка терміну безпечної експлуатації КР енергоблока № 1 ВП РАЕС з використанням залежності $T_{k}$ та початкової і уточненої залежностей $\Delta T_{F}$

Як видно з Рисунка 4 за $T_{k}^{a}=177^{\circ} \mathrm{C}$ ресурс КР енергоблока № 1 ВП РАЕС під час розрахунку $T_{k} 3$ використанням:

вихідної залежності $\Delta T_{F}$ (P=0,041\%) забезпечений до 2038 р. включно (58 років експлуатації).

уточненої залежності $\Delta T_{F}(\mathrm{P}=0,041 \%)$ забезпечений до 2018 р. включно (38 років експлуатації).

Експертні оцінки ресурсу КР задовільно узгоджувались із оцінками ЕО і на підставі цих даних ДП «НАЕК «Енергоатом»/ВП РАЕС було ухвалено і Держатомрегулюванням погоджено рішення про проведення відновлювального відпалу КР енергоблока № 1 ВП РАЕС, як реалізація заходу з УС, що дозволить відновити вихідні механічні властивості металу КР майже до початкових значень і стане гарантією безпечної експлуатації в запланований 30-річний період ДСЕ.

Відновлювальний відпал зварного шва № 4 КР енергоблока № 1 ВП РАЕС було виконано в період з 19.09.2010 по 28.09.2010. Усі вимоги з температурно-часового режиму відновлювального відпалу зварного шва № 4 КР були виконані в повному обсязі. За результатами відновлювального відпалу був проведений повторний TLAA на опір крихкому руйнуванню. Результати розрахунку наведено в Таблиці 1.

Таблиця 1 - Результати розрахунку на опір крихкому руйнуванню зварного шва № 4

\begin{tabular}{|c|c|c|c|}
\hline $\begin{array}{c}\text { Елемент } \\
\text { КР }\end{array}$ & $\mathrm{T}_{\text {ка' }}{ }^{\circ} \mathrm{C}$ & $\begin{array}{c}\mathrm{T}_{\mathrm{k}} \text { на кінець } \\
\text { строку служби } \\
60 \text { років, }{ }^{\circ} \mathrm{C}\end{array}$ & $\begin{array}{c}\text { Запас за } \\
\text { температурою }_{\mathrm{K}_{\mathrm{K}}\left(\mathrm{T}_{\text {ка }}-\mathrm{T}_{\mathrm{K}}\right),{ }^{\circ} \mathrm{C}}\end{array}$ \\
\hline $\begin{array}{c}\text { Зварне } \\
\text { 3'єднання } \\
\text { № } 4\end{array}$ & 177 & 160 & 17 \\
\hline
\end{tabular}

Отже, результати TLAA на опір крихкому руйнуванню засвідчили виконання критерію на 60 років експлуатації із запасом за температурою $\mathrm{T}_{k}\left(\mathrm{~T}_{\text {ка }}-\mathrm{T}_{\mathrm{k}}\right)-$ $17^{\circ} \mathrm{C}$. На поточний час значення зсуву $\mathrm{T}_{\mathrm{K}}$ уточнюються за результатами випробувань ЗС модернізованої програми ЗС у межах ППБ.

Втома/оцінка циклічної міцності головного роз'єму КР блока № 3 ВП РАЕС. Цей TLAA оцінює ступінь поточної втоми металу і дозволяє зробити прогноз часу до моменту появи втомних тріщин, оцінює значення пошкоджуваності і дотримання критерію [а] <1 (де а - пошкоджуваність).

Цей TLAA $\epsilon$ обов'язковим і виконується для обладнання та трубопроводів АЕС на стадії проєктної експлуатації і під час переходу до ДСЕ. Розрахунок на циклічну міцність/втому виконується відповідно до вимог ПНАЭ Г-7-002-86 [24]. Умова міцності за наявності різних циклічних навантажень перевіряється за формулою:

$$
\sum_{i=1}^{k} \frac{N_{i}}{\left[N_{0}\right]}=a \leq\left[a_{N}\right] .
$$

Під час проведення робіт з перепризначення строку служби КР, головного роз'єму реактора (ГРР) та верхнього блока блока № 3 результати цього TLAA засвідчили, що умова циклічної міцності не виконується для середньої нарізної ділянки шпильки і гайки ГРР для 60 років експлуатації. Було визначено, що вагомий внесок у втомну пошкоджуваність шпильок вносить процес затягування шпильок під час ущільнення головного роз'єму реактора, тобто режим 1.1.1 «Заповнення обладнання (реактора) робочим середовищем, ущільнення обладнання». Для цього режиму кількість циклів для розрахунку втоми була прийнята на підставі підсумовування зареєстрованої і прогнозної кількості циклів. 
3 огляду на зазначене, був виконаний альтернативний розрахунок циклічної міцності шпильки і гайки, для якого за минулий період експлуатації для режиму 1.1.1 «Заповнення обладнання (реактора) робочим середовищем, ущільнення обладнання» враховувались тільки цикли із затягом ГРР.

На Рисунку 5 наведено результати розрахунків накопиченої втомної пошкоджуваності залежно від строку експлуатації (кількості кампаній) для середньої нарізної ділянки шпильки для двох варіантів:

варіант 1: розрахунок виконаний з урахуванням припущення, що за минулий період експлуатації всі зареєстровані режими 1.1.1 «Заповнення обладнання (реактора) робочим середовищем, ущільнення обладнання» супроводжувались затягом ГРР $(\mathrm{a}=1,41 \mathrm{E}+00)$;

варіант 2: альтернативний розрахунок, виконаний з урахуванням кількості режимів 1.1.1 «Заповнення обладнання (реактора) робочим середовищем, ущільнення обладнання», за яких відбувався фактичний затяг ГРР за минулий період експлуатації $(\mathrm{a}=1,15 \mathrm{E}+00)$.

Ураховуючи дані, наведені на Рисунку 5, накопичена втомна пошкоджуваність за альтернативним розрахунком досягне допустимого значення, коли кількість режимів 1.1.1 «Заповнення обладнання (реактора) робочим середовищем, ущільнення обладнання» дорівнюватиме 77. Зважаючи на те, що за минулий період експлуатації для альтернативного розрахунку прийнято 31 режим 1.1.1 «Заповнення обладнання (реактора) робочим середовищем, ущільнення обладнання» із затягом ГРР, до досягнення допустимого значення накопиченої втомної пошкоджуваності залишається ще 46 циклів на період ДСЕ.

Релаксація арматурних канатів 30. TLAA оцінює потенційні втрати попередньо напружених елементів з метою визначення часу для проведення заходів із заміни або відновлення.

Досвід виконання оцінки поточного технічного стану 30 реакторів типу BBEP-1000/B-320 на AEC України в межах робіт з продовження строку їх експлуатації, виявив необхідність уточнення мінімально допустимих зусиль натягу арматурних канатів системи попереднього напруження 30 та аналізу поведінки 30 з урахуванням нових отриманих сейсмічних даних і в умовах аварії, зокрема важкої [29]. 3 визначенням нових значень мінімально допустимих зусиль натягу арматурних канатів актуальним стало питання встановлення граничного значення надлишкового тиску і температури в умовах запроєктної аварії, під час яких 30 втрачає свої захисні функції. Отримання цього значення необхідно для його обліку під час виконання ймовірнісного аналізу безпеки другого рівня.

Результати такого TLAA дослідження актуальні для їх урахування під час ухвалення регулюючих рішень про можливість ДСЕ 30 та забезпечення виконання передбачених проєктом її локалізуючих функцій. Під час виконання подібних досліджень ураховується не тільки релаксація в канаті з погляду мінімально допустимих значень зусиль, а й властивості бетону та арматури.

Особливості моделі 30 для таких розрахунків за даними [30] наведені на Рисунку 6.

Розрахунки підтвердили надійність 30 у разі сполучення різних видів впливів у проєктних режимах, зокрема визначили мінімально-допустимі зусилля натягу в арматурних канатах у разі поєднання навантажень нормальна експлуатація + проєктна аварія + проєктний землетрус. Безпечний строк експлуатації системи герметичного огородження локалізуючої системи безпеки був обґрунтований на період до 31.12.2053 р. Результати розрахунків наведені в Рішенні 190-130-Р-18 [31].

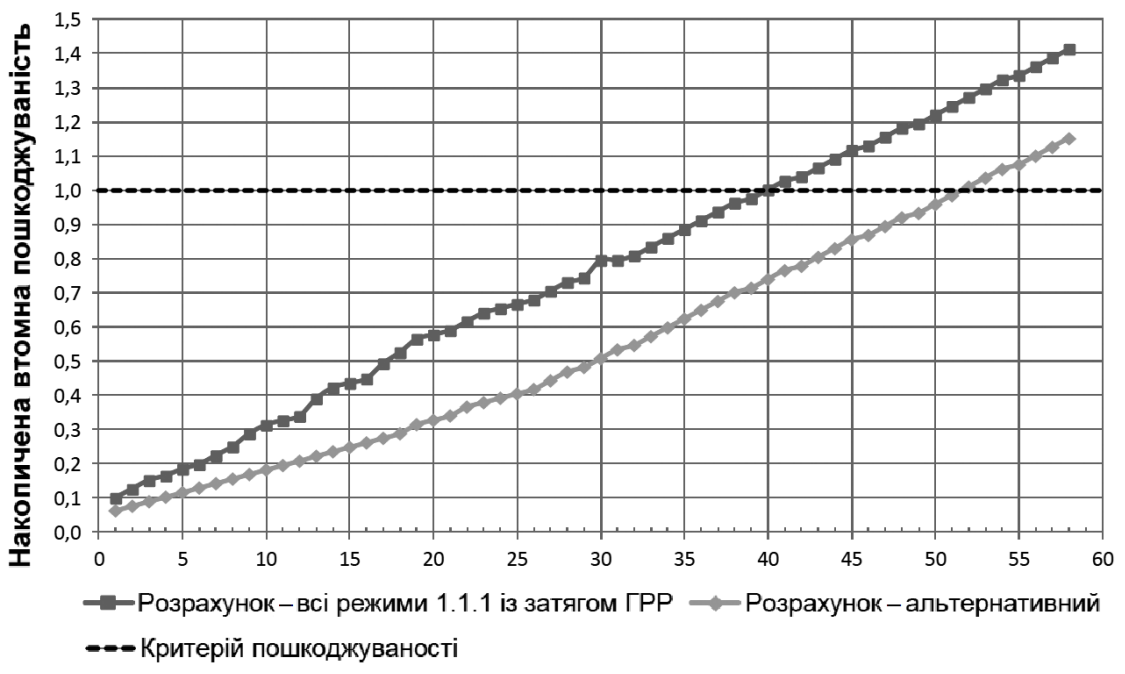

Кампанія

Рисунок 5 - Накопичена втомна пошкоджуваність шпильки (середня різьбова ділянка) 


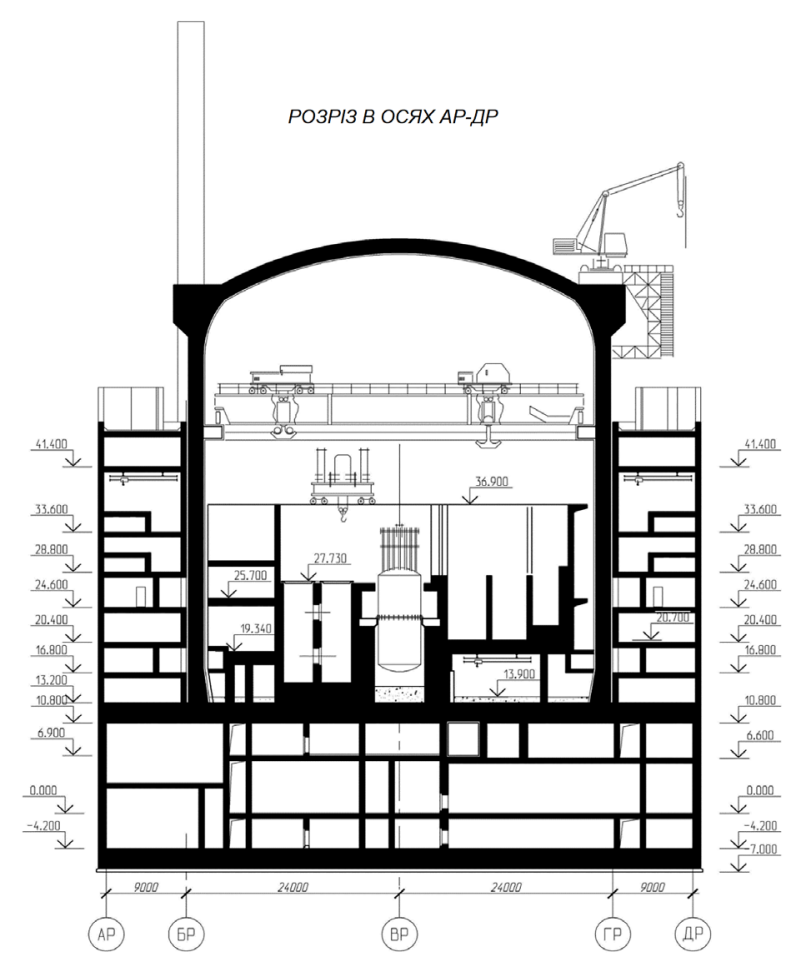

а) Загальний вигляд 30

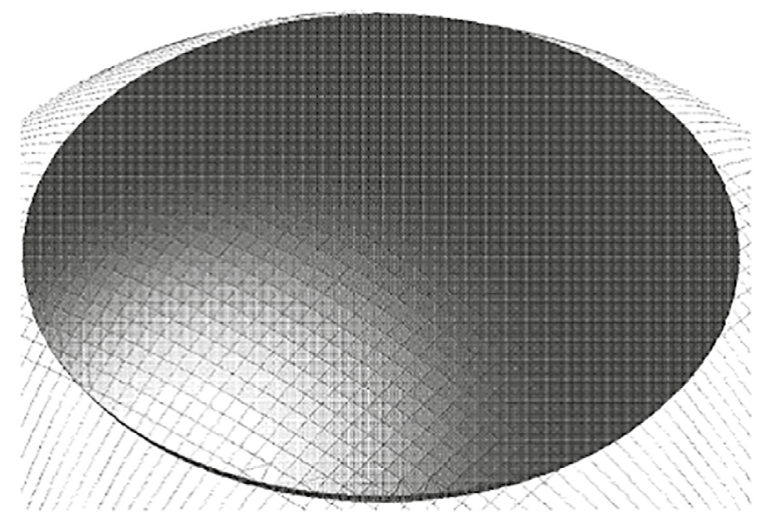

в) Купольна частина 30

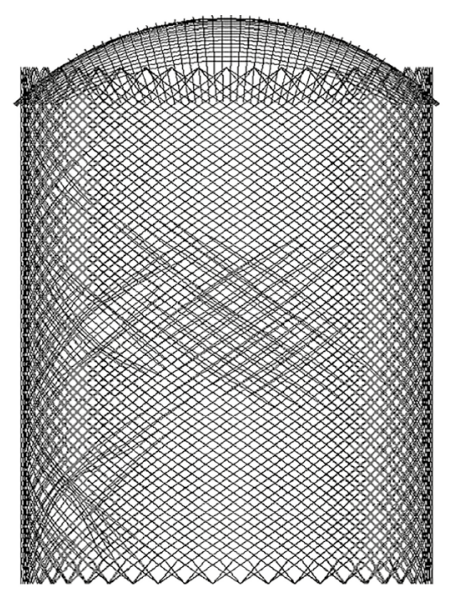

д) Система попереднього напруження 30

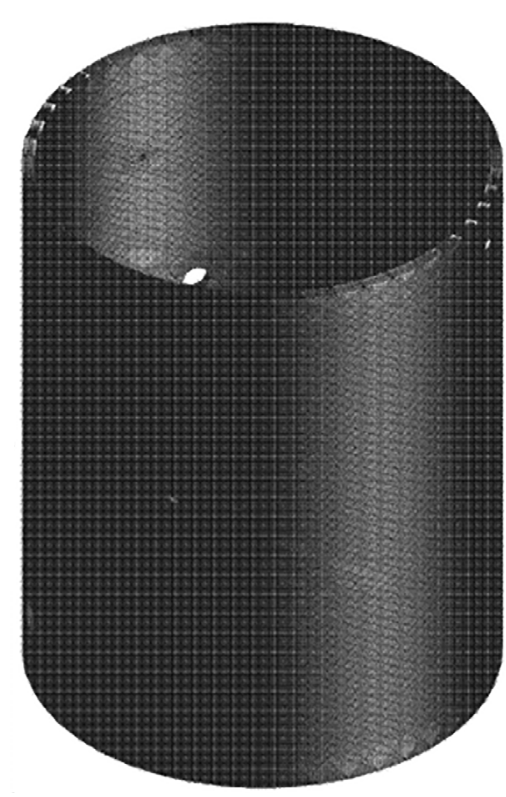

б) Циліндрична частина 30

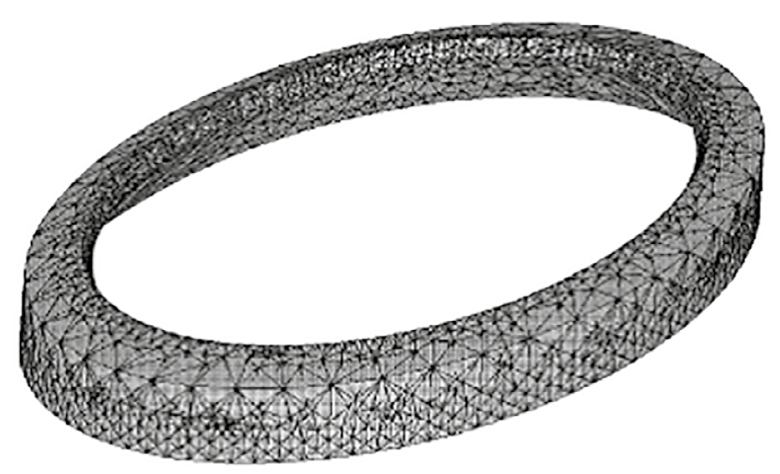

г) Карнизна частина 30

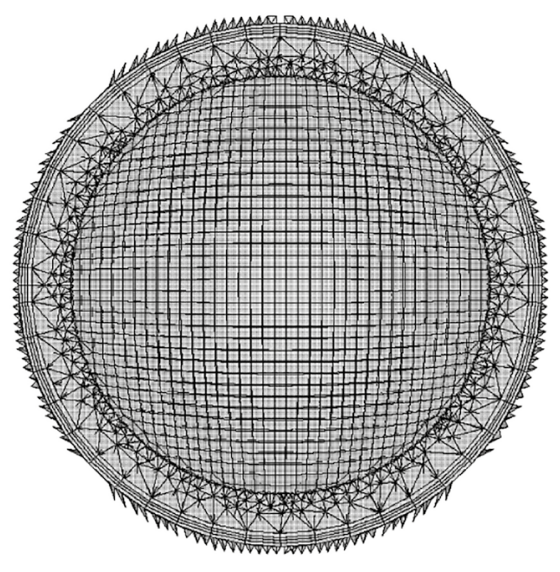

є) Купольна частина 30

Рисунок 6 - Особливості моделі 30 


\section{5 Загальне співставлення підходів до вимог TLAA}

Критерії успішності застосування TLAA та випадки його використання в різних країнах розглянуті в [32]. Досвід впровадження TLAA свідчить про їх значне поширення і застосування під час переоцінки безпеки, протягом реалізації ПУС, в період переходу до ДСЕ в багатьох країнах світу з урахуванням низки винятків. Світовий досвід і практика використання та застосування TLAA були ретельно проаналізовані в межах робочої групи МАГАТЕ 3 узагальнення міжнародного досвіду щодо УС і наведені в документі SRS-82 [8].

Результати такого узагальнення дозволили сформувати перелік TLAA, які застосовуються в різних країнах (див. Таблицю 2).

\section{Висновки щодо практики застосування TLAA в Україні та світі}

Одним з основоположних аспектів під час переходу до ДСЕ є виконання TLAA.

Підсумовуючи дослідження досвіду і практики застосування TLAA в США, країнах Європи та Україні можна зробити такі узагальнюючі висновки:

принципи, покладені в основу TLAA, і перелік застосовуваних TLAA, здебільшого, однаковий у всіх країнах і базується на узагальнених рекомендаціях МАГАТЕ, викладених у SSG-48 [2] i SRS-82 [8], однак можуть уточнюватися і відрізнятися залежно від національних вимог;

схеми переходу до ДСЕ розрізняються залежно від національних регулюючих вимог, але, як правило, належать до двох основних типів - ППБ 3 використанням TLAA або поглиблений аналіз

Таблиця 2 - Приклади TLAA за даними SRS-82 [8]

\begin{tabular}{|c|c|c|c|}
\hline $\begin{array}{l}\text { № } \\
\Pi / \Pi\end{array}$ & $\begin{array}{c}\text { Позначення } \\
\text { TLAA }\end{array}$ & $\begin{array}{c}\text { Назва TLAA } \\
\text { (англійською) }\end{array}$ & $\begin{array}{c}\text { Назва TLAA } \\
\text { (українською) }\end{array}$ \\
\hline \multicolumn{4}{|c|}{ I TLAA для механічних компонентів } \\
\hline 1 & TLAA 101 & Low-cycle Fatigue Usage & Малоциклова втома \\
\hline 2 & TLAA 102 & RPV Neutron Embrittlement & Радіаційне окрихчення КР \\
\hline 3 & TLAA 103 & Crack Growth Analyses & Аналіз росту тріщин \\
\hline 4 & TLAA 104 & Corrosion Allowances & Припуски на корозію \\
\hline 5 & TLAA 106 & Environmentally Assisted Fatigue & $\begin{array}{l}\text { Втомне пошкодження внаслідок впливу } \\
\text { довкілля }\end{array}$ \\
\hline 6 & TLAA 107 & $\begin{array}{l}\text { High-cycle Fatigue for Steam Generator } \\
\text { Tubes }\end{array}$ & \begin{tabular}{|lccc}
$\begin{array}{l}\text { Високоциклічна } \\
\text { парогенератора }\end{array}$ & втома & для & трубок \\
\end{tabular} \\
\hline 7 & TLAA 108 & Fatigue of Cranes & Втома кранів \\
\hline 8 & TLAA 109 & PWR RPV Internals Swelling & Розпухання ВКП реакторів типу PWR \\
\hline 9 & TLAA 110 & $\begin{array}{l}\text { Thermal Ageing of Cast Austenitic Stainless } \\
\text { Steels }\end{array}$ & $\begin{array}{l}\text { Термічне старіння аустенітних нержавіючих } \\
\text { сталей }\end{array}$ \\
\hline 10 & TLAA 112 & Main Circulation Pump Flywheel & \begin{tabular}{|lll} 
Аналіз старіння маховика головного \\
циркуляційного насосу
\end{tabular} \\
\hline 11 & TLAA 113 & Thermal Stratification & Теплова стратифікація \\
\hline 12 & TLAA 115 & $\begin{array}{l}\text { Fatigue and Thermal Ageing Analysis of } \\
\text { Manufacturing Flaws }\end{array}$ & $\begin{array}{llll}\text { Аналіз втоми та } & \text { термічного старіння } \\
\text { заводських дефектів } & & \\
\end{array}$ \\
\hline \multicolumn{4}{|c|}{ II TLAA для електричних компонентів та інформаційних і керуючих систем (IKC) } \\
\hline 13 & TLAA 201 & $\begin{array}{l}\text { Environmental Qualification of Electrical } \\
\text { and I\&C Components }\end{array}$ & $\begin{array}{l}\text { Кваліфікація електричних кабелів та } \\
\text { обладнання IKC на умови навколишнього } \\
\text { середовища }\end{array}$ \\
\hline \multicolumn{4}{|c|}{ III TLAA для будівель та споруд } \\
\hline 14 & TLAA 301 & Concrete Containment Tendon Prestress & $\begin{array}{l}\text { Переднапружений стан арматури бетону } \\
\text { контайнменту }\end{array}$ \\
\hline 15 & TLAA 303 & $\begin{array}{l}\text { Cumulative Fatigue Damage of Containment } \\
\text { Liners and Penetrations }\end{array}$ & $\begin{array}{lrr}\text { Накопичена } & \text { втомна } & \text { пошкоджуваність } \\
\text { облицювання } & \text { контайнменту } \\
\text { гермопроходок } & & \\
\end{array}$ \\
\hline 16 & TLAA 304 & $\begin{array}{l}\begin{array}{l}\text { Foundation Settlement Due to Soil } \\
\text { Movement }\end{array} \\
\end{array}$ & Осідання фундаменту внаслідок зсуву ґрунту \\
\hline
\end{tabular}


безпеки в рамках поновлення ліцензії, однак теж з використанням TLAA;

у всіх країнах існує єдина вимога щодо необхідності складання переліку обладнання, що підлягає УС, і визначення тих компонентів, для яких повинні бути виконані аналізи TLAA;

для всіх країн обов'язковою умовою $є$ розробка і впровадження ПУС. Окремі ПУС (наприклад, за механізмами деградації) безпосередньо пов'язані з однойменними TLAA (наприклад, для реалізації програми моніторингу втоми (АМР 101 - Fatigue Monitoring) виконується відповідний TLAA101 Low-cycle Fatigue Usage).

Досвід впровадження TLAA свідчить про їх значне поширення і застосування під час переоцінки безпеки, протягом реалізації ПУС, у період переходу до ДСЕ в багатьох країнах світу, що також підтверджується висновками за роботою [33].

\section{Список використаної літератури}

1. Safety of Nuclear Power Plants: Commissioning and Operation. IAEA Safety Standards Series No. SSR-2/2 (Rev. 1). Vienna: IAEA, 2016. 47 p.

2. Ageing Management and Development of a Programme for Long Term Operation of Nuclear Power Plants. IAEA Safety Standards Series No. SSG-48. Vienna: IAEA, 2018. 65 p.

3. 10 CFR Part 54 - Requirements for Renewal of Operating Licenses for Nuclear Power Plants.

4. NEI 95-10, Industry Guidelines for Implementing the Requirements of 10 CFR 54 - The License Renewal Rule. Revision 6. Washington: Nuclear Energy Institute, June 2005.

5. Periodic Safety Review for Nuclear Power Plants. IAEA Safety Standards Series. Specific Safety Guide No. SSG-25. Vienna: IAEA, 2013. $106 \mathrm{p}$.

6. Conceptual document LTO «Bewijsvoering» KCB. NRG-report NRG-22701/10.103460, 9 September 2011.

7. Ageing Management for Nuclear Power Plants: International Generic Ageing Lessons Learned (IGALL), Safety Reports Series No. 82. Vienna: IAEA, 2015. 87 p.

8. SSMFS 2008:17. The Swedish Radiation Safety Authority's regulations and general advice concerning the design and construction of nuclear power reactors. Swedish Radiation Safety Authority Regulatory Code. 30 January 2009.

9. NUREG-1801. Rev. 2. Generic Aging Lessons Learned (GALL) Report. Office of Nuclear Reactor Regulation, 2010.

10. Ageing Management for Nuclear Power Plants. IAEA Safety Standards Series No. NS-G-2.12. Vienna: IAEA, 2009. 48 p.

11. 10 CFR Part 50 - Domestic Licensing of Production and Utilization Facilities.
12. NEI 95-10, Revision 6. Industry Guidelines for Implementing the Requirements of 10 CFR 54 - The License Renewal Rule. Nuclear Energy Institute, June 2005.

13. NUREG-1800. Rev. 2. Standard Review Plan for Review of License Renewal Applications for Nuclear Power Plants. Office of Nuclear Reactor Regulation, 2010.

14. Instrucción IS-22, sobre gestión del envejecimiento y operación a largo plazo de centrales nucleares. Consejo de Seguridad Nuclear, 2009.

15. Guía de Seguridad 1.10 (Rev. 1). Revisiones periódicas de la seguridad de las centrales nucleares. Madrid: Consejo de Seguridad Nuclear, 2008.

16. Safe Long Term Operation of Nuclear Power Plants, Safety Reports Series No. 57, Vienna: IAEA, 2008. 33 p.

17. Decree No. 162 of 2017 on Requirements for Safety Assessment pursuant to the Atomic Act.

18. Guide YVL A.8/20 May 2014. Ageing Management of a Nuclear Facility. Radiation and Nuclear Safety Authority (STUK), 2014. [Translation in English].

19. HAEA Guideline 1.28. Version 2. Regulatory procedures of operation beyond design lifetime. Budapest, 2013.

20. HAEA Guideline 4.14. Version 2. Activities to be implemented by the operator to support the license application for operation beyond design lifetime. Budapest, 2013.

21. НП 306.2.210-2017. Загальні вимоги до управління старінням елементів і конструкцій та довгострокової експлуатації егергоблоків атомних станцій. Затвердж. наказом Держатомрегулювання від 13.04.2017 № 136, зареєстровані в М-ві юстиції України 05.05.2017 за № 578/30446.

22. СОУ НАЕК 080:2014. Эксплуатация технологического комплекса. Долгосрочная эксплуатация действующих энергоблоков АЭС. Общие положения. Затвердж. наказом ДП «НАЕК «Енергоатом» від 23.01.2015 № 74.

23. СОУ НАЕК 141:2017. Инженерная, научная и техническая поддержка. Управление старением элементов и конструкций энергоблока АЭС. Общие требования. Затвердж. наказом ДП «НАЕК «Енергоатом» від 13.07.2017 № 577.

24. ПНАЭГ-7-002-86. Нормы расчета на прочность оборудования и трубопроводов атомных энергетических установок. М.: Энергоатомиздат, 1989.

25.РДЭО 0606-2005. Методика расчета на сопротивление хрупкому разрушению корпусов реакторов АЭС с ВВЭР при эксплуатации (МРКР-СХР-2004).

26. TAREG 2.01/00. Обоснование степени нейтронного охрупчивания корпусов реакторов ВВЭР-1000 и BВEP-440/213 с целью оценки их целостности: технический отчет № TAREG2.01-00/SC-31.0260/DIA/R/TR/08 01 001-01. Переоценка базы данных образцов-свидетелей реакторов (BВEP-1000 \& ВBEP-440/213). Часть 2: ВВEP-440/213 (финальная версия). РНЦ Курчатовский институт, Москва, 2008.

27. Звіт про виконання державної експертизи ядерної та радіаційної безпеки рішення щодо продовження терміну експлуатації корпуса реактора енергоблоку № 1 ВП «Рівненська АЕС» з обгрунтовуючими матеріалами. Звіт № 09-09-4928. К., 2009.

28. Корпус реактора. Расчет на сопротивление хрупкому разрушению. 1 блок Ровенской АЭС. У213-Р-1921. 
29. Дослідження поведінки захисної оболонки та армоканатів для РУ ВВЕР-1000/В-320 в умовах проектної та запроектної аварії. Визначення мінімально допустимих зусиль натягу арматурних канатів в системі переднапруження захисної оболонки з урахуванням нового рівня сейсмічності при сполученні навантажень проектна аварія та проектний землетрус. (Завдання 24 Угоди 257586 від 29.03.2016, етап 1): звіт про виконання НДР. Київ, ДНТЦ ЯРБ. 2019. 126 с.

30. Отчет по результатам проверочных расчетов элементов и конструкций локализующей системы безопасности системы герметичного ограждения энергоблока № 3 ОП «Ривненская АЭС. 1087-12-03.00-ПР». ООО «Фундаментстроймакс», Днепропетровск, 2014.

31. О продлении срока эксплуатации конструкций системы герметичного ограждения локализующей системы безопасности энергоблока № 3 Ривненской АЭС: річний звіт. 190-130-Р-18.

32. Технический отчет «Изучение аналитических рекомендаций и опыта выполнения анализов старения, определяющих срок службы (TLAA). (Договір про надання послуг № 01/051-20 між ДНТЦ ЯРБ і ТОВ «Технео Глобал»)».

33. Шугайло Ол-й П., Гребенюк Ю.П., Зелений О.В., Рижов Д.І., Шугайло Ол-рП., Брік Д.С., Черняк Я.П. Отриманий досвід та вивчені уроки щодо діяльності 3 переходу енергоблоків АЕС України до довгострокової експлуатації. Ядерна та радіаційна безпека. 2020. № 1(85). C. 15 - 28. doi: 10.32918/nrs.2020.1(85).02.

\section{References}

1. IAEA Safety Standards Series No. SSR-2/2 (Rev. 1). Safety of Nuclear Power Plants: Commissioning and Operation. International Atomic Energy Agency. Vienna, 2016.

2. IAEA Safety Standards Series No. SSG-48. Ageing Management and Development of a Programme for Long Term Operation of Nuclear Power Plants. International Atomic Energy Agency. Vienna, 201865 p.

3. 10 CFR Part 54. Requirements for Renewal of Operating Licenses for Nuclear Power Plants.

4. NEI 95-10. Industry Guidelines for Implementing the Requirements of 10 CFR 54 - The License Renewal Rule, Revision 6. Washington: Nuclear Energy Institute, June 2005.

5. IAEA Safety Standards Series. Specific Safety Guide No. SSG-25. Periodic Safety Review for Nuclear Power Plants. International Atomic Energy Agency. Vienna, 2013, 106 p.

6. NRG-report NRG-22701/10.103460. Conceptual document LTO «Bewijsvoering» KCB. 9 September 2011.

7. Safety Reports Series No. 82. Ageing Management for Nuclear Power Plants: International Generic Ageing Lessons Learned (IGALL). International Atomic Energy Agency. Vienna, $2015,87 \mathrm{p}$.
8. SSMFS 2008:17. The Swedish Radiation Safety Authority's Regulations Concerning the Design and Construction of Nuclear Power Reactors.

9. NUREG-1801. Generic Aging Lessons Learned (GALL) Report, Rev. 2. Office of Nuclear Reactor Regulation, 2010.

10. IAEA Safety Standards Series No NS-G-2.12. Ageing Management for Nuclear Power Plants. International Atomic Energy Agency. Vienna, 2009, 48 p.

11. 10 CFR Part 50. Domestic Licensing of Production and Utilization Facilities.

12. NEI 95-10, Revision 6. Industry Guidelines for Implementing the Requirements of 10 CFR 54 - The License Renewal Rule. Nuclear Energy Institute, June 2005.

13. NUREG-1800. Rev. 2. Standard Review Plan for Review of License Renewal Applications for Nuclear Power Plants. Office of Nuclear Reactor Regulation, 2010.

14. Instrucción IS-22 Sobre Gestión del Envejecimiento y Operación a Largo Plazo de Centrales Nucleares. Consejo de Seguridad Nuclear, 2009.

15. Guía de Seguridad 1.10 (Rev. 1). Revisiones Periódicas de la Seguridad de las Centrales Nucleares. Madrid, Consejo de Seguridad Nuclear, 2008.

16. IAEA Safety Reports Series No.57. Safe Long Term Operation of Nuclear Power Plants. International Atomic Energy Agency. Vienna, 2008, 33 p.

17. Decree No. 162. Requirements for Safety Assessment pursuant to the Atomic Act. 2017.

18. Guide YVL A.8/20. Ageing Management of a Nuclear Facility. Radiation and Nuclear Safety Authority (STUK). May 2014.

19. HAEA Guideline 1.28 Regulatory Process of the License Renewal. Budapest, 2013.

20. HAEA Guideline 4.14. Version 2. Activities to be Implemented by the Operator to Support the License Application for Operation beyond Design Lifetime. Budapest, 2013.

21. NP 306.2.210-2017. General Requirements for Aging Management of Elements and Structures and Long-Term Operation of Nuclear Power Plants..

22. SOU-N NAEK 080:2014. Operation of the Technological Complex. Long-term Operation of NPP Power Units. General Provisions.

23. SOU-N NAEK 141:2017. Engineering, Scientific and Technical Support. Aging Management of Elements and Structures of the NPP Power Unit. General Requirements.

24. PNAE G-7-002-86. Standards for Strength Calculations of NPP Equipment And Piping. Energoatomizdat, 1989.

25. RD EO 0606-2005. Method for Brittle Fracture Resistance Calculating of NPP Reactor Vessels with VVER (MRKR-SKhR).

26. TAREG 2.01/00. Justification of Neutron Embrittlement Degree of WWER-1000 and WWER-440/213 RPVs in order to Assess their Integrity. Technical Report No. TAREG2.01-00 / SC-31.0260 / DIA / R / TR / $0801001-$ 01. Reassessment of Reactor Witness Samples Database (WWER-1000 \& WWER-440/213). Part 2: VVER-440/213 (final version). RRC Kurchatov Institute, Moscow, 2008.

27. Report No. 09-09-4928. Report on the Implementation of the State Review on Nuclear and Radiation Safety of the Decision to Extend the Operation Life of the Reactor Pressure Vessel of Power Unit No. 1 of Rivne NPP with Supporting Materials. 
28. U213-R-1921. Reactor Pressure Vessel. Calculation of Brittle Fracture Resistance. Power Unit No. 1 of Rivne NPP.

29. Report on the implementation of research work. Analysis of WWER-1000/320 Containment and Tendons under DesignBasis and Beyond Design-Basis Accidents. Determination of the Minimum Allowed Tension of Tendons in the Containment Prestressing System Considering the new Seismic Level under a Combination of Design-Basis Accident and Operating-Basis Earthquake. (Task 24 of the Agreement 257586 dated March 29, 2016, stage 1)». Kyiv, 2019, 126 p.

30.1087-12-03.00-PR. Report on the Results of Elements and Structures of the Localizing Safety System of the Containment System Verification Calculations for Power Unit No. 3 of the Rivne NPP. LLC «Fundamentstroymaks», Dnepropetrovsk, 2014.

31. 190-130-R-18. On the Life-Time Extension of the Structures of the Containment System of the Confining Safety System of Power Unit No. 3 of the Rivne NPP.

32. Technical Report. Analytical Recommendations Study and Acting Time Limited Aging Analysis (TLAA) Experience. (Under the Service Agreement No. 01/051-20 between SSTC NRS and Techneo Global LLC).

33. Shugailo O., Grebenyuk Yu., Zeleny O., Ryzhov D., Shugailo Ol-r., Brick D., Cherniak Ya. (2020). Experience Gained and Lessons Learned on Transition of Ukrainian NPPs Power Units to Long-Term Operation Activity. Nuclear and Radiation Safety, 1 (85), 15 - 28. doi: 10.32918 / nrs.2020.1 (85).02.

\section{The Main Requirements for TLAA and Practice of Their Application in Ukraine and in the World}

\author{
Shugailo O-i', Kazymyrska O. ${ }^{2}$, Brik D. ${ }^{1}$, \\ Chumel B.', Banko S.'
}

\footnotetext{
${ }^{1}$ State enterprise «State Scientific and Technical Center for Nuclear and Radiation safety», Kyiv, Ukraine

${ }^{2}$ Separated entity «Rivne NPP» of the National Nuclear Energy Generating Company «Energoatom», Varash, Rivne region, Ukraine
}

Aging management (AM) is considered to be one of the main factors in ensuring safe operation of nuclear power plants (NPPs) at the stages of design and long-term operation (LTO). As defined by the IAEA, aging management for NPPs is carried out in order to reduce the impact of aging effects on the performance of structures, systems and components (SSCs) of their design safety functions during the service life of NPP (including decommissioning). It requires taking into account both the consequences of physical aging of SSCs, which lead to performance deterioration, and non-physical aging of SSCs (its aging in comparison with the current state of development of science and technology). Therefore, the analysis of the state of the AM issue is given appropriate attention both in Ukraine and in the world. One of the main components of aging management is the performance of Time Limited Aging Analysis (TLAA). In fact, it is the TLAA results that can be interpreted as the lifetime of a particular component or structure. This article presents the main requirements and criteria for successful application of TLAA according to the IAEA recommendations, presents the main results of practical application analysis of TLAA in Europe and the United States (approaches to assessing aging and methodology for developing AM programs are analyzed). The experience of Ukraine in transition to LTO based on TLAA is analyzed, typical TLAA are considered, which are performed during the periodic safety reassessment to justify the LTO of Ukrainian NPPs (resistance to brittle fracture of the RPV, fatigue / assessment of the reactor main seal cyclic strength, stress relaxation of prestressed steel tendons of containment). In addition, the article compares national and international approaches to requirements of TLAA, and also draws appropriate conclusions.

Keywords: TLAA, long-term operation, aging management, safety analysis, periodic safety reassessment, effects of aging.

Отримано 17.02.2021 